\begin{tabular}{l} 
MARTIN LUTHER SE \\
MET VESKOUING VAN DIE EKUMENE \\
BINNE DIE FEDERASIE \\
\hline KERKE IN SUIDER -AFRIKA
\end{tabular}

\title{
G.J. Beyers
}

"Hulle leer dat die een heilige Kerk vir ewig sal voortbestaan. Hierdie kerk is die vergadering van die gelowiges warbinne die Evangelie korrek geleer en die sakramente reg bedien word. Vir die eenheid van die Kerk is dit voldoende om eenheid van geloof te hê met betrekking tot die leer van die Woord en die bediening van die sakramanete. Dit is nie nodig dat dieselfde menslike tradisies, ritusse en seremonies orals geleer word nie." (Augsburgse Konfessie. Artikel 7).

Ek wil $u$ aandag vestig op bogenoemde aanhaling uit die Augsburgse Konfessie wanneer ons vir h wyle gaan stilstaan by die tema: Martin Luther se beskouing van die Ekumene met verwysing na die kontemporêre situasie binne die Federasie van Evangelies-Lutherse Kerke in Suider Afrika. On hierdie tema deeglik in oënskou te neem, sal ons dit bespreek in twee dele en wel aan die hand van die volgende indeling: A: Martin Luther se ekumeniese beskouing en $B$ : die kontemporêre situasie binne die genoemde Lutherse Federasie.

A. Luther se ekumeniese visie soos dit na vore kom in die Augsburgse Konfessie. Artikel 7 kan slegs na warde geskat word aan die hand van die volgende hoofde: I. Oorsprong. II. Inhoud en III. Betekenis.

1. Ten eerste dan: In 1521 word Luther verban en die Evangeliese beweging veroordeel te Worms. Keiser Karel $V$ poog om die Protestante en die Katolieke te versoen en belê derhalwe die Ryksdag van Augsburg vir 1530. Luther, vanweë sy verbanning laat alles aan Melanchton oor wat bemerk dat ten spyte van die Thorgause Artikels hulle op dogmatiese gebied geheel en al onvoldoende voorbereid was. Die Augsburgse Konfessie was die produk van sy en ander se hernude ywer. Hierdie Belydenis, bestaande uit twee hoofdele, se primêre betekenis was versoenend van aard gewees, sowel teenoor die zwingliane as teenoor die Katolieke. In Artikel 1 tot 21 gaan dit om die hoofmomente van die Christelike geloof en dan veral oor drie sake - reguerdigmaking, prediking en die Kerk van Christus. In die gees van versoening 
verwater Melanchton die verskille met die Roomse Kerk deur te sê dis hoofsaaklik prakties van aard en nie leerstellig nie. Op die $25 s t e$ Junie 1530 word dit aan die Ryksdag van Augsburg voorge1อ.

II. Dit bring ons dan by die tweede hoofgedagte, naamlik die inhoud van artikel 7. Ter inleiding net dit: hierdie artikel moet saam met Artike 5 gelees en verstaan word waar dit gaan om die gawe van die Gees wat aan die Woord en sakramente verbind word. Woord en sakramente werk geloof en versterk dit en dit bepaal en definieer die eenheid van die Kerk.

Die sentrale gedagte van hierdie artikel handel oor die eenheid van die heilige Kerk. Hierdie eenheid rus op twee pilare naamlik die bediening van die Woord en sakramente in warheid. Vir Luther was dit in Bybelse opdrag. 'n Opdrag om eenheid na te streef ten spyte van die verskille. Matteüs 28:19 en Efesiërs 4:4 - 5 vorm vir hom die agtergrond warteen hy sy ekumeniese bande met die Katolieke Kerk aan die eenkant en Zwingli aan die ander kant gesien het. Dit bly en is egter nie net ' $n$ Godgegewe opdrag nie. Dit is ook $h$ doelwit op sigself. In die bereiking van die doelwit - eenheid - word die opdrag - eenheid - dan ook uitgevoer.

Hoe word hierdie opdrag uitgevoer? Die doelwit bereik? Deur in die ekumeniese gesprek vas te hou aan die twee pole van Woord en sakramente. So word eenheid bereik. Die korrekte siening van hierdie twee elemente is geensins die voorwaarde tot eenheid nie. Inteendeel, al het $n$ kerk net $\mathrm{n}$ sekere mate van hierdie warhede beet, sien Luther dit nogtans as sy opdrag om thet hulle in eenheidsgesprek te tree.

Wat bedoel Luther egter as hy van eenheid praat? On ' $\mathrm{n}$ antwoord hierop te vind, moet ons op sy Ekklesiologie let. Die Kerk bestaan uit twee onderskeibare, tog nie skeibare entiteite wat mekaar interpreteer - die sigbare en die onsigbare Kerk. Die ware Kerk is nie afgeskei van die empiriese Kerk nie. Die Kerk is daar waar God deur sy Woord en sakramente werksaam is en dit kan orals wees, selfs al wyk die offisiële leer van h spesifieke kerk af van die ware en korrekte beskouinge volgens God se Woord. Dit gaan dus om die algemene priesterskap van die gelowiges en die gelowiges is daar war die Woord en sakramente bedien 
word om geloof in Christus te werk. Om Christen te wees, beteken om th lidmaat van die ware en sigbare Kerk te wees. Die Kerk is dus die gemeenskap van die gelowiges wat versamel word deur Woord en sakramente. Die Kerk is geen instituut wat oor die gelowiges heen bestaan nie en is dus ook geen bemiddelaar tussen die gelowige en Christus nie. Daarom is die Kerk b lewende gemeenskap wat as samebindingsfaktor het die strewe na eenheid deur vas te hou aan die ware Woord-verkondiging en die korrekte sakramentsbediening.

III. Ten derde - hoe het Luther dit prakties ten uitvoer gebring? Die konkrete betekenis van sy ekumeniese strewe na eenheid het hy in twee rigtings gesien, met die Rooms Katolieke kerk en met ander Protestantse Kerke, by name met Zwingli en Calvyn. Otn $n$ duidelike idee te vorm van sy strewe is dit genoegsaam om te let op die eersgenoemde rigting.

Die eenheidsstrewe met die Katolieke Kerk is van besondere belang aangesien hy in 1520 uit hierdie Kerk verban is. Ten spyte daarvan het hy nooit ontken dat Rome nie ook deel van die universele kerk is nie. Sy lewe het hy gewy aan die hervorning en reiniging, eers van binne, daarna van buite van hierdie Kerk. Die eenheid van die Kerk was geensins ondergeskik aan die leer en dogma-verskille nie. Vir hom het dit gegaan om die een heilige vergadering en gemeente van ware heiliges wat geregeer word deur een Hoof, Jesus Christus en geroep deur een Gees en in een geloof. Derhalwe bly die Roomse Kerk vir hom voorwerp van sy strewe tot eenheid ten spyte van n verdraaide Evangelie beskouing wat nogtans ware en korrekte elemente van die skrif, sakramente en geloof bevat het. Alhoewel Rome menslike en Goddelike faktore vermeng het en sekondêre aspekte vereis het vir saligmaking, keer Luther hulle nie die rug nie. Hy poog om die eenheid te bereik deur middel van konsilies, waar die Kerk gehoor word en die leer vry aan die lig kon kom. Sodoende kon beide kerke se foute uitgewys geword het ter wille van die eenheid van die Kerk van Christus. Rome het hierdie aanbod van die hand gewys!

Luther as ekumeniese pionier het besef dat die ware eenheid van die Kerk van Christus eers by die wederkoms bereik sal word. Dit het hom egter nie weerhou van $h$ aktiewe, teenswoordige soeke na hierdie eenheid nie. Daarvan is Art. 7 van die Augsburgse Konfessie n duidelike bewys. Eenheid as opdrag rus op die inhoud van die woord en die sakramente en op grond hiervan het hy dit ook prakties uitgeleef en as doelwit gestel. 
B. Staan ons dan nou stil by die kontemporêre situasie binne die EvangeliesLutherse Kerke in Suid-Afrika dan spreek dit vanself dat ons uitgaan van twee voorveronderstellings. Dit is die ekumeniese siening soos deur die FELKSA beoefen en hoe dit veral ten opsigte van die Ned. Geref. Kerk funksioneer. FEIKSA of te wete die Federasie van Evangelies-Lutherse Kerke in Suider Afrika se strewe is tweeledig: interne Lutherse eenheid en eksterne eenheid met ander geselekteerde Kerke.

Wat interne strewe betref gaan hulle gebuk onder in tweespalt wat loop langs die grense van kleur, naamlik swart en wit. Binne die raamwerk van in agt tot vyf swart meerderheid het die blanke lidmate, hoofsaaklik van Duitse herkoms, angs en vrees dat hulle sal verdwyn te midde van hierdie meerderheidsverhouding. Alhoewel alle Lutherse Kerke dieselfde kerkregering, belydenis en liturgie aanhang, kon hulle tot op hede nog net op 23 gebiede eenheid bewerkstellig het. Dit is $h$ verskeidenheid van gebiede maar die wat hoog op die prioriteitslys is, is sake soos reg en geregtigheid, hervestiging van anderskleuriges en versoening op politieke vlak, dit as gevolg van die politieke bedeling waarbinne hulle leef. Dus, die Lutherane in Suider Afrika se strewe na eenheid op grond van die Woord en sakramente figureer nog, tog is dit heelwat polities gekleurd.

Die eksterne strewe moet dan ook gesien word vanuit hierdie gesigspunt. Die Blanke lidkerke is bereid om met die Ned. Geref. Kerk in gesprek te tree - soos dan telkens op sporadiese wyse gebeur. Die Boulevard-samesprekings van 1972 is $h$ bewys hiervan. Die feit van die saak is egter so dat die gesprekke sporadies en om onverklaarbare redes nie op gereelde grondslag plaasvind nie. Dr P. Rossouw en andere verklaar heel tereg as hulle sê dat beide Kerke Reformatoriese Kerke is wat naby aan mekaar staan en wat ook t.o.v. die Augsburgse Konfessie in noue kontak met mekaar leef.

Die redes vir FELKSA en die Ned. Geref. Kerk se mislukte ekumeniese pogings is te vinde in die Swart Lutherse Kerke se houding. Hierdie houding is geheel en al polities gekleurd. Reeds so ver terug as 1957 verklaar Mchane Nun dat die eenheid van die Kerk moet berus op politieke aspekte eerder as op leerstellinge en geloofsake. Die keuse-beslissing of daar gesprek noet wees al dan rie moet slegs berus by Afrika-teoloë, geinterpreteer Swart teoloë. Die 1975 oproep uit Swakopmund en die 1977 Gaberone en die daaropvolgende Lutherse Wêreld Bond-konfessies te Dar es Salaam bevestig dit. Vandag is dit so dat 
hierdie Kerke skakeling het met die SARK, WRK, LWB en ook met nie-kerk1ike instansies soos die Suid-Afrikaanse Instituut vir Rasse Aangeleenthede. Hulle beskou die NGSK as die verteenwoordiger en die spreekbuis van die Ned. Geref. Kerke familie. Hoekom wil hulle in ekumeniese gesprek tree met bogenoemde instansies? Omrede hulle uitgesproke anti-regeringsverklarings en optredes veral wat betref die groepsgebiede en hervestigings-beleide van die huidige regering. Die Ned. Geref. Kerk is volgens hulle napraters van die sogenaamde apartheidspolitiek van die Nasionale Party. In 1977 vaardig hulle dan ook $h$ oproep uit vir die eenheid van die Lutherse Christene met ander Christene wat prakties en polities eendersdenkend is.

Beantwoord hierdie siening nog aan Luther se ideaal van Ekumenisme? Nee, inderdaad nie. Hier is geen sprake van die funksionering van Woord en sakramente nie. Hier is geen sprake van h eenheidsstrewe al het die ander kerk, en dan by name die Ned. Geref. Kerk net nog deelsgewys die waarheid beet nie. Nee, op grond van politieke oorweginge is hier nie meer sprake van $n$ soeke na die eenheid van die Kerk van Christus nie.

Tog, moet ons, nie net die Ned. Geref. Kerk nie, mar ook ander Protestantse en Calvinistiese Kerke ons hande in eie boesem steek en die hand van eenheid uitstrek tot hierdie kerke wat op grond van politieke oorwegings die ekumeniese strewe uit die oog verloor het. Luther was self die voorbeeld van iemand wat altyd die ander wang gedraai het, wat altyd bereid was om homself te ondersoek aan die hand van die Woord van God. Dit het hy alles altyd gedoen ter wille van die eenheid van die Kerk van Christus. Wie is ons dan om te sê nee, ons sal nie vergewe nie. In die FELKSA is daar tog elemente van waarheid aanwesig in hulle beskouinge oor die Woord en sakramente en al sê hulle ons het nie meer elemente van warheid nie, of miskien weerhou eksterne faktore soos die politiek hulle van kontak met ons, laat ons van ons kant die opdrag van God in gedagte hou.

Ons het net soos Luther 'n opdrag tot eenheid ontvang en daarom moet ons ook die doelwit van eenheid nastreef. 